\title{
Mite infection of Carabus violaceus in rural forest patches and urban parks
}

\author{
SZABOLCS MIZSER ${ }^{1}$ \\ LEILA NAGY2 \\ BÉLA TÓTHMÉRÉSZ1 \\ ${ }^{1}$ MTA-DE Biodiversity and Ecosystem Services \\ Research Group, Egyetem square 1, Debrecen \\ $\mathrm{H}-4032$ Hungary, \\ 2 Department of Ecology, University of Debrecen \\ P.O.Box 400, Debrecen, H-4002 Hungary

\section{Correspondence:} \\ Szabolcs Mizser \\ E-mail:mizserszabolcs@gmail.com \\ List of abbreviations: \\ C. violaceus $=$ Carabus violaceus \\ M. glaber $=$ Macrocheles glaber \\ P. carabi = Poecilochirus carabi \\ $\mathrm{p}=$ significance level
}

Keywords: urbanization, prevalence, Mesostigmata, live-capture traps
Received January 15, 2016.

Revised July 25, 2016.

Accepted July 25, 2016.

\begin{abstract}
Background and purpose We investigated phoretic mite (Acari: Mesostigmata) infection of Carabus violaceus (Coleoptera: Carabidae) in rural forest patches and urban forested parks in and around Debrecen city, Hungary. We hypothesized that the prevalence of mite infection, mean abundance, mean and median intensity of mites is higher in rural forest patches than in urban parks.
\end{abstract}

Materials and methods We collected C. violaceus individuals using live-capture pitfall traps and preserved them frozen. We identified and counted each mite of the host beetle individuals. Chi ${ }^{2}$, Bootstrap t-test, Mood's median test were used.

Results We trapped altogether 199C. violaceus individuals (101 in the rural forest patches and 98 in the urban parks). There were 250 phoretic mite individuals on the $\mathrm{C}$. violaceus representing two species (Poecilochirus carabi, Macrocheles glaber). We found 224 mite individuals in the rural forest patches, and 26 in the urban parks. We found that the prevalence, mean abundance, mean and median intensity of phoretic mites were significantly higher in the rural forest patches, than in the urban parks.

Discussion The studied phoretic mite species use beetles only for transfer and not harming them. Thus, the prevalence and mean intensity of these species depend primarily on the number of available prey density. The cause of decreased number of these phoretic mite species in the urban forest patches should be investigated in more details analysing the effect of disturbance due to urbanisation on a mite fauna and evaluating mite infection on carabids as potential bioindication of habitat disturbances or degradation.

\section{INTRODUCTION}

Cities are densely populated, built-up, developed and often highly disturbed areas, with isolated fragments of the original habitats ( 1 , 2). These remnants of the original habitats are markedly different from the natural ones; they are usually warmer and drier than the original habitats (3); thus, they are partly inhospitable habitats for the native species adapted to the local environmental conditions (4).

Ground beetles are excellent ecological indicators; numerous studies focused on their responses to urbanization and human disturbance (5, 6). Most of the papers concentrate on the assemblages, and do not examine the populations and/or individuals, but see (7). There is some information about life cycle of ground beetle species (8), but there is a gap in our knowledge about their interactions with mites.

The studied host species was Carabus violaceus Linnaeues, 1758. The average body size of this species is $28.0 \mathrm{~mm}$ in this region (9). This beetle 
is an eurytopic, mesophilic, flightless, brachypter species. Wings are reduced, elytra are fused. Its surface is black, lateral margins of pronotum and elytra are more or less blue, purple or violet (10). This is a forest species, which is abundant not only in the rural forest patches but also in the urban parks $(4,7)$. This beetle is a nocturnal predator, the ratio of its day activity is less than $15 \%$ (11). During the day it can be found resting under woods, stones or leaf litter. It consumes mainly slugs, snails, various ground-living insects and their larvae, spiders, earthworms. The larva is also predator, although less swift than the adult form. The seasonal activity depends on the regions and altitude (12). Most larvae hibernate and adults appear at the end of spring and reproduce in summer. Generations overlap.

Mesostigmata is one of the most diverse taxa of mites. The adult of several species are predators, consuming mainly fly eggs, larvae and nematodes $(13,14)$. The nymphs are common phoretics of carabids and other beetles, using them for transport (13). Phoresy means that mites attached to the beetles exclusively for transport. They are causing no harm for the host, although they may hamper them in motion.

The aim of our study was to explore phoretic mite infection of Carabus violaceus in rural forest patches and urban parks. The following hypotheses were tested: (i) the prevalence and mean abundance of phoretic mites are higher in the rural forest patches than in the urban parks. (ii) The mean and median intensity of phoretic mites also higher in the rural forest patches than in the urban parks.

\section{MATERIAL AND METHODS}

\section{Study area and sampling design}

The study area was in and around the city of Debrecen (Eastern Hungary). All selected areas were in a once-continuous old native oak forest association (Convallario-Quercetum roboris). There were two sampling area, a rural forest and an urban forested park. In the rural area there were no buildings and roads. In the urban area the built-up area exceeded 60\%. The selected species was collected at each area using live-capture pitfall traps, randomly placing 20 traps at least $10 \mathrm{~m}$ from each other at each site. Traps were emptied daily from the beginning of May until the end of October in 2010 and 2011. There was no bait in the traps. All trapped Carabus violaceus individuals were separated from each other, and the beetles with their mites were preserved frozen. Mites were identified to species level using standard keys $(15,16,13)$. The mites on surface and in subelytral cave were counted and preserved in $70 \%$ ethanol.

\section{Data analyses}

Prevalence of mite infection, mean abundance of mites, mean and median intensity of mites were calculated. Prevalence is the proportion of infected individuals in the sample. Mean abundance is based on all the trapped individuals. Calculation of the mean and median intensity is based on only the infected individuals.

Chi ${ }^{2}$-test and Mood's median test were used to compare the prevalence and the median intensity of the rural forest patches and the urban parks. Bootstrap t-test was used to test differences in the mean abundance and mean intensity of phoretic mites. During the calculations QP 3.0 were used (17).

\section{RESULT}

During the study we trapped altogether 199 C. violaceus individuals; there were 101 individuals in the rural forest patches and 98 individuals in the urban parks. We found 224 phoretic mite individuals on $C$. violaceus in the rural forest patches, and 26 phoretic mite individuals on C. violaceus in the urban parks. Two phoretic mite species were found on the studied ground beetles: Poecilochirus carabi (44 individuals), and Macrocheles glaber (206 individuals). The prevalence, mean and median intensity of phoretic mite species were significantly higher in the rural forest patches than in the urban parks (prevalence: $\mathrm{p}<0.005$, Chi-square statistic $=49.044$, d.f. $=1$; mean intensity: Bootstrap p-value (two-sided $)=0.005$, t-statistic $=$ -3.34; median intensity: exact p-value (two-sided) $=0.034$ ) (Table 1). The mean abundance of phoretic mite species was also significantly higher in the rural forest patches (mean abundance: $\mathrm{p}<0.01$, t-statistic $=-7.25$ ) (Fig. 1).

Table 1. Number of hosts and their infection in the rural forest patches and urban parks.

\begin{tabular}{|lccccc|}
\hline \multicolumn{3}{|c}{ No. of hosts } & \multicolumn{3}{c|}{ Intensity } \\
\hline & Total & Infected & Prevalence & Mean & Median \\
\hline $\begin{array}{l}\text { Rural forest } \\
\text { patches }\end{array}$ & 101 & 62 & $61.4 \%$ & 3.61 & 3.0 \\
Urban parks & 98 & 13 & $13.3 \%$ & 2.00 & 1.0 \\
\hline
\end{tabular}

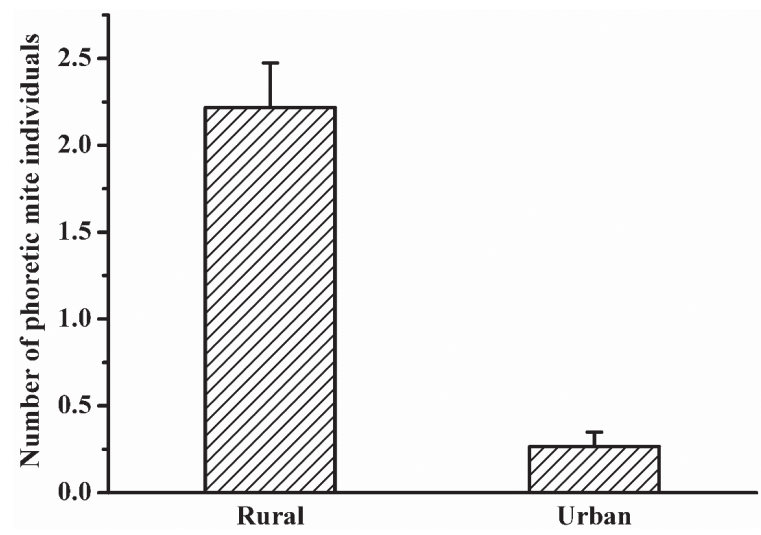

Figure 1. Number of phoretic mite individuals per host in the rural forest patches and urban parks (mean $\pm S E$ ). 


\section{DISCUSSION}

There are only few data published about the Hungarian Mesostigmata fauna (18). During this study we identified two phoretic mite species (Macrocheles glaber, and Poecilochirus carabi) on the studied host beetle (C. violaceus). The development of these mites takes a few days, usually 3 days (14). The nymphs use the beetles only for transfer and they do not harm directly the host species. The adult forms of these mites are free-living predators and feed mainly on fly eggs and first instar larvae. The female of $M$. glaber and $P$. carabi can destroy more than $13-18$ fly eggs a day $(14,19)$. There are only a few published data about the potential prey abundance (20). In most cases they found that the abundance of Diptera species decreased towards the urban area (20), but most papers concentrate only one species or families of flies.

Both of our hypotheses were confirmed. In the urban parks the mean abundance and prevalence of phoretic mites were lower than in the rural forest patches. A possible reason is that the abundance of these species rather depends on the number of potential prey individuals than on the viability of $C$. violaceus (20). Furthermore, it is also important to note that $P$. carabi prefers the carrion beetles for transfer. Carabids usually infected by not only phoretic mites, but also by Astigmata mites. Several species of the Astigmata mites are paraphagous; and they are obligate external or subelytral paraphages of adult beetles (13). Distribution of these mites may influence the feeding and reproduction of carabids. Thus, it would be necessary to know more facts about the roles of mites influencing the distribution of carabids and other arthropods.

Acknowledgement. We are grateful to Jenő Kontschán for his help in the mite identifications. The study was supported by the SROP-4.2.2.B-15/1/KONV20150001 project, and the Hungarian Academy of Sciences and Hungarian Research Found (OTKA K-116639). The research of Szabolcs Mizser was supported by the European Union and the State of Hungary, co-financed by the European Social Fund in the framework of TÁMOP 4.2.4.A/2-11-1-2012-0001 'National Excellence Program'.

\section{REFERENCES}

1. GIBB H, HOCHULI D F 2002 Habitat fragmentation in an urban environment large and small fragments support different arthropod assemblages. Biol Conserv 106: 91-100 http://dx.doi.org/10.1016/S0006-3207(01)00232-4

2. MAGURA T, LÖVEI, G, TÓTHMÉRÉSZ B 2010 Does urbanisation decrease diversity in ground beetle (Carabidae) assemblages? Glob Ecol Biogeogr 19: 16-26 http://dx.doi.org/10.1111/j.1466-8238.2009.00499.x
3. MARSHALL E, SHORTLE J 2005 Urban development impacts on ecosystems. In: GOETZ S, SHORTLE J, BERGSTROM J (eds) Land use problems and conflicts: causes, consequences and solutions. Routledge, New York, pp. 79-93

4. MAGURA T, TÓTHMÉRÉSZ B, MOLNÁR T 2004 Changes in carabid beetle assemblages along an urbanization gradient in the City of Debrecen, Hungary. Landsc Ecol 19: 747-759 http://dx.doi.org/10.1007/s10980-005-1128-4

5. TÓTHMÉRÉSZ B, MÁTHÉ I, BALÁZS E, MAGURA T 2011 Responses of carabid beetles to urbanization in Transylvania (Romania). Landsc Urban Plan 101: 330-337 http://dx.doi.org/10.1016/j.landurbplan.2011.02.038

6. MAGURA T, BOGYÓ D, MIZSER S, NAGY D D, TÓTHMÉRÉSZ B 2015 Recovery of ground-dwelling assemblages during reforestation with native oak depends on the mobility and feeding habits of the species. For Ecol Manage 339: 117-126

7. MAGURA T, LÖVEI G, TÓTHMÉRÉSZ B 2008 Time-consistent rearrangement of carabid beetle assemblages by an urbanisation gradient in Hungary. Acta Oecol 34: (2) 233-243 http://dx.doi.org/10.1016/j.actao.2008.05.010

8. ANDORKÓ R, KÁDÁR F 2009 Life-history characteristics of the ground beetle Carabus scheidleri (Coleoptera: Carabidae) in Hungary. Acta Zool Acad Sci H. 55 (4): 381-393

9. MAGURA T, TÓTHMÉRÉSZ B, LÖVEI G 2006 Body size inequality of carabids along an urbanisation gradient. Basic Appl Ecol 7: 472-482 http://dx.doi.org/10.1016/j.baae.2005.08.005

10. HŮRKA K 1996 Carabidae of the Czech and Slovak Republics. Kabourek, Zlin, p 565

11. THIELE 1977 Carabid beetles in their environments. Springer, New York, USA, p 369

12. TURIN H, PENEV L, CASALE A 2003 The Genus Carabus in Europe. A Synthesis. Fauna Europaea Evertebrata. No 2. Pensoft, Sofia, p 512

13. KRANTZ W, WALTER DE 2009 Manual of Acarology. Third Edition. Texas Tech University Press, Lubbock Texas, p 807

14. SABAH I AL-DULAIMI 2002 Predation by the mite Macrocheles glaber (Müller) (Acarina: Macrochelidae) on the house fly Musca Domestica L. with some notes on its biology. Bull Iraq nat Hist Mus 9 (4): 7-11

15. KONTSCHÁN J 2005 Contribution to the Macrochelidae fauna of Hungary (Acari: Mesostigmata). Fol Hist-Nat Mus Matr 29: 77-80

16. KONTSCHÁN J $2007 \mathrm{New}$ and rare Mesostigmatid mites to the fauna of Hungary. Fol Hist-Nat Mus Matr 31: 99-106

17. RÓZSA L, REICZIGEL J, MAJOROS G 2000 Quantifying parasites in samples of hosts. J Parasitol 86: 228-232 http://dx.doi. org/10.1645/0022-3395(2000)086[0228:QPISOH]2.0.CO;2

18. KONTSCHÁN J 2006 Check list of the Hungarian Mesostigmatid mites I.-II. Zerconidae and Macrochelidae. Fol Hist-Nat Mus Matr 30: 129-136

19. WISE G U, HENNESSEY M K, AXTELL R C 1988 A New Species of Manure-Inhabiting Mite in the Genus Poecilochirus (Acari: Mesostigmata: Parasitidae) Predacious on House Fly Eggs and Larvae. Entomol Soc Am 81 (2): 209-224 http://dx.doi.org/10.1093/aesa/81.2.209

20. GIBBS J P, STANTON E J 2001 Habitat fragmentation and arthropod community change: Carrion beetles, phoretic mites, and flies. Ecol Appl 11 (1): 79-85 http://dx.doi.org/10.1890/10510761(2001)011[0079:HFAACC]2.0.CO;2 
